\title{
Corporation's Criminal Liability in Indonesia: A Response to the Weak Enforcement of Corporate Social Responsibility
}

\author{
Syukri Kurniawan \\ Diponegoro University, Indonesia \\ syukrikurniawan28@gmail.com \\ Hari Sutra Disemadi \\ Batam International University, Indonesia \\ hari@uib.ac.id
}

\begin{abstract}
Corporate Social Responsibility (CSR) is a corporate commitment to contribute to sustainable economic development by focusing on the balance between attention to economic, social, and environmental aspects. This paper argues that corporations are subject to criminal law, which can be subject to criminal liability if they do not carry out CSR obligations. This study aims to find out the linkage of sanctions arrangements and the urgency of regulations on criminal liability if the corporation does not carry out CSR obligations. In practice, CSR is only based on corporate awareness and commitment. In the meantime, CSR enforcement's most basic weakness is the absence of strict sanctions for corporations that deny CSR, especially in terms of criminal sanctions. Instead, the sanction is limited to administrative as set out in Act No. 25/2007 on Investment, with a lack of legislation governing criminal sanctions against CSR prevention. In so doing, there is a need to introduce sanctions against corporations that deny CSR, by taking into account adverse impacts to the environment and community.
\end{abstract}

KEYWORDS: Corporate Social Responsibility, Criminal Liability, Corporations.

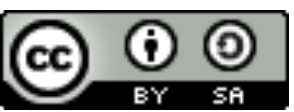

Copyright $\odot 2020$ by Author(s)

This work is licensed under a Creative Commons Attribution-ShareAlike 4.0 International License. All writings published in this journal are personal views of the authors and do not represent the views of this journal and the author's affiliated institutions.

\section{HOW TO CITE:}

Kurniawan, Syukri \& Disemadi, Hari Sutra. "Corporation's Criminal Liability in Indonesia: A Response to the Weak Enforcement of Corporate Social Responsibility" (2020) 7:2 Lentera Hukum 209-230.

Submitted: February 12, 2020 Revised: July 16, 2020 Accepted: July 23, 2020 


\section{INTRODUCTION}

Corporate is a term commonly used by criminal and criminal law experts and the field of civil law as a legal entity, or in the Dutch language called "rechtpersoon" or in English with the term legal person or legal body. ${ }^{1}$ It can be said that a corporation is a legal business entity that is a legal entity. ${ }^{2}$ Today, it is not enough for corporations to focus solely on economic growth, but synergizing various forces need a new business paradigm within the corporation circle with forces outside the corporation (stakeholders). The synergy that a corporation successfully builds will inevitably flow to external support, strengthening the corporation's position amid increasingly fierce and globalized competition. ${ }^{3}$

One way to realize cooperation is through the social and environmental responsibility program to translate the term Corporate Social Responsibility (CSR). ${ }^{4}$ In principle, CSR emphasizes that corporations do not position themselves as ivory towers and elitist institutions that isolate themselves from the surrounding environment. However, without the support of stakeholders, the existence of a corporation will never be realized. They exist, grow, and develop because of the recognition and carrying capacity of stakeholders who support them directly and indirectly. The mutual support will occur mutually beneficial between the two parties. According to Budiman et al., in the book Business Ethics in Islamic Perspective, stakeholders include the government, investors, suppliers, customers, political groups, community workers, and trade associations. ${ }^{5}$

At present developments, corporations turn out that corporate responsibility does not only lie in looking for maximum profits or dividends but must also be based on social and environmental consequences for now and for the long term. ${ }^{6}$ The corporation must also be morally responsible to other stakeholders besides the shareholders. CSR is a form of corporate responsibility towards the environment for social care and environmental responsibility by not ignoring the corporation's capabilities. ${ }^{7}$ The implementation of these obligations must consider and respect the communities' cultural traditions around the location of the business activities. ${ }^{8}$

Setiyono, Kejahatan Korporasi (Malang: Banyumedia Publishing, 2009) at 2.

Disemadi, H.S., \& Jaya, N.S.P., "Perkembangan Pengaturan Korporasi Sebagai Subjek Hukum Pidana Di Indonesia”, Jurnal Hukum Media Bhakti, 3(2), 118-127, (2019) at 119.

3 Djakfar, M., "Corporate Social Responsibility: Aktualisasi Ajaran Ihsan Dalam Bisnis." Ulul Albab Jurnal Studi Islam, 11(1), 1l1-130 (2013) at 113.

4 Utama, A.S., \& Rizana., "Pelaksanaan Corporate Social Responsibility Dalam Rangka Optimalisasi Pelestarian Lingkungan," Litigasi, 19(2), 127-147 (2020) at 129.

5 Iqbal, M., \& Sudaryanto, T. "Tanggungjawab Sosial Perusahaan (Corporate Social Responsibility) dalam Perspektif Kebijakan Pembangunan Pertanian," Analisis Kebijakan Pertanian, 6 (2), 155-173, (2016) at 158.

6 Disemadi, H. S., \& Prananingtyas, P. "Kebijakan Corporate Social Responsibility (CSR) sebagai Strategi Hukum dalam Pemberdayaan Masyarakat di Indonesia," Jurnal Wawasan Yuridika, 4(1), 116 (2020) at 4.

7 Carroll, A.B., "Corporate Social Responsibility: Evolution of a Definitional Construct," Business \& Society, 38(3), 268-295 (1999) at 270.

8 Disemadi, H. S. "Consumer Protection of Flight Services through Corporate Social Responsibility Implementation in Indonesia," Journal of Private and Commercial Law 4 (1), 14-21 (2020) at 18. 
CSR has now begun to be applied in several regulations that apply in Indonesia, among others, in Law Number 25 of 2007 concerning Investment (Investment Law) and Law Number 40 of 2007 concerning Company Limited (Law Limited Liability Companies). Both of these laws explicitly require that to implement a corporation that carries out the principles of good corporate governance or Good Corporate Governance (GCG) must also care about the corporation's social and environmental interests that carry out the duties and implementation of the corporation in the natural resource sector. ${ }^{9}$

This arrangement intends to support the establishment of harmonious, balanced, and compatible corporate relations with the environment, values, norms, and culture of the local community, so it is determined that corporations whose business activities in the fields and/or related to natural resources are required to carry out social responsibility and environment. Corporations carrying out their obligations, then social and environmental responsibility activities, must be budgeted and calculated as corporate costs carried out due to propriety and fairness. These activities must be included in the corporate annual report. If the corporation does not carry out social and environmental responsibility, the corporation concerned will be subject to sanctions under statutory provisions.

Corporations must continue to carry out CSR obligations because corporations are legal subjects that can be held accountable if they do not implement CSR. In the current era of globalization, legal subjects are not only limited to natural people but also include corporations. ${ }^{10}$ The existence of corporations as legal subjects in implementing CSR has a crucial role in developing a country so that corporations can potentially not implement CSR and may be subject to sanctions, both administrative and criminal sanctions." The adoption of corporate understanding as a criminal law subject means that corporations, as both legal entities and non-legal entities, are considered capable of carrying out criminal acts and can be accounted for in criminal law. ${ }^{12}$ Corporate liability may be imposed on the corporation, or the corporate management can be held criminally responsible for an act committed for and on behalf of the corporation. ${ }^{13}$

According to Muladi, there are several justification reasons why corporations are recognized as perpetrators of crime. One of these reasons is based on integralist philosophy, in which everything should be measured based on balance, harmony, and harmony between individual interests and social interests. ${ }^{14}$ The recognition of

9 Hasnati., Dewi, S., \& Utama, A.S., "Perbandingan Prinsip Good Corporate Governance Pada Bank Konvensional dan Bank Syariah dalam Sistem Hukum di Indonesia," Mizan: Journal of Islamic Law, 3(2), 197-208 (2019) at 199.

10 Kashyap, R., Mir, R., \& Mir, A., "Corporate Social Responsibility: A Call for Multidisciplinary Inquiry," Journal of Business \& Economics Research, 2(7), 51-58 (2004) at 52.

Il Utama, A.S., \& Rizana, supra note 4 at 140.

12 Muladi, \& Priyatno, D., Pertanggungjawaban Pidana Korporasi (Jakarta: Kencana, 2009) at 43.

13 Muladi, \& Priyatno, D., supra note 6 at 51.

14 Hatrik, H., Asas Pertanggungjawaban Pidana Korporasi Dalam Hukum Pidana Indonesia (Bandung: Alumni, 1996) at 36. 
corporations as subject to criminal law seems to have worldwide. It was proven, among others, by holding the 14th international conference on the "Criminal Liability of Corporation" in Athens from July 31 to August 6, 1994. Where among other things, Finlandia, which initially did not regulate corporations as subjects of criminal law, but in its development, has recognized the corporation as a criminal law subject and can be accounted for.

Penalties against corporations that do not implement CSR needs to be done because the impact of losses caused by corporations can be detrimental to the surrounding community. ${ }^{15}$ The corporation carries out activities in the area around the residents' settlements. As a result, the corporation has the responsibility to give feedback on what is obtained since it was founded. The corporation receives profits that are many times the corporation's activities, so if the corporation does not implement CSR, the corporation is given sanctions.

Previous research on CSR was conducted by Erwin Syahputra and Suteki in 2017, which focused on poverty alleviation through the law to empower corporate social responsibility;16 Dani Amran Hakim, and Budi Ispriyarso in 2016 focused on fulfilling labor rights through the implementation of corporate social responsibility in a company; 17 and Andrew Shandy Utama, and Rizana in 2017 who implemented the company's corporate social responsibility towards the community of Sri Meranti Village Pekanbaru City. ${ }^{18}$ In contrast to previous research, current research focuses on the urgency of regulating corporate criminal liability against not implementing CSR.

\section{SETTINGS CORPORATE SOCIAL RESPONSIBILITY LIABILITY IN INDONESIA}

The development of law in Indonesia makes most corporations have business activities related to natural resources that carry out their company's operational activities by using corporate licenses in the form of legal entities in the form of Limited Liability Companies (Perseroan Terbatas or PT). Limited Liability Company, as a legal subject, still has the rights and obligations provided by law.

Law is a necessity inherent in social life in society, namely that the law will serve members of the community, allocate power, distribute resources, and protect the interests of members of the community itself. Therefore the law becomes essential as the means to realize that law is a vital instrument for realizing specific objectives,

15 Syahputra, E., \& Suteki, "Strategi Baru Pengentasan Kemiskinan Melalui Hukum Sebagai Sarana Pemberdayaan Corporate Social Responsibility", Masalah-Masalah Hukum, 46(1), 1-8 (2017) at 3.

16 Syahputra, E., \& Suteki. supra note 6, at 1.

17 Hakim, D. A., \& Ispriyarso, B. "Pemenuhan Hak-Hak Tenaga Kerja Melalui Penerapan Corporate Social Responsibility Pada Suatu Perusahaan (Studi Penerapan CSR Di PT. Great Giant Pineapple, Provinsi Lampung)", Law Reform, 12(2), 197-208 (2016) at 197.

18 Utama, A. S., \& Rizana. "Implementasi Corporate Social Responsibility PT Riau Crumb Rubber Factory Terhadap Masayarakat Kelurahan Sri Meranti Kota Pekanbaru”, Jurnal Hukum Novelty $8(2), 173-186(2017)$ at 173 . 
making law a means that is consciously and actively used to regulate society through the use of deliberate legal regulations. ${ }^{19}$

An advanced legal system with legal drafting and development is professionally and logically designed. There is no doubt that legal products can influence, even change the joints of people's lives. ${ }^{20}$ It is just that a legal product is changed, either by parliament, government, or the court. In advance, there has been a shout/need in the community for the change. The faster the law responds to the voice of legal reform/change in society, the greater the law's role for the change in that society. Conversely, the slower the law responds to the voices of reform in society, the smaller the function and share of law in changing that society because the community has already changed itself first. The law serves only as ratification and legitimacy so that in cases like this, it is not the law that changes society, but developments that change the law.

Some CSR supporters separate CSR from social contributions and "good deeds" or generosity, such as humanity's habitat. This suggests the possibility of CSR originating from corporations' social activities by setting aside some of the profits. In essence, social donations remain one small part of CSR. Concern for the surrounding community/community relations can be briefly understood as increasing the organization's participation and position in a community through various joint benefit efforts for the organization and community.

CSR is not just a mere charity. CSR requires a corporation to make decisions that must seriously consider the impact on stakeholders, including the environment. ${ }^{21}$ The development of CSR in foreign countries has been prevalent. This can be seen from the concept of CSR that continues to experience development. Whereas the implementation of CSR in Indonesia is currently more popular as a voluntary action from corporations, CSR implementation depends very much on the commitment and norms of corporate ethics to the surrounding social and environmental conditions. ${ }^{22}$ The attention of policymakers towards CSR shows an awareness that there is a potential for adverse impacts from corporate operational activities. These adverse impacts must, of course, be reduced in such a way that they do not endanger the benefit of the community while remaining friendly to the business climate.

Herein lies the importance of regulating CSR in Indonesia, so that it has a governing, binding, and driving force. CSR, which was initially voluntary, needs to be upgraded to CSR, which is more mandatory. Thus, it can be expected that the business community is a measured and systematic contribution to improving people's welfare. Policies that are pro-community and environment like this are needed amidst the

19 Rahardjo, S., Hukum Dalam Perspektif Sejarah Sosial Dalam Pembangunan Hukum Dalam Perspektif Politik Hukum Nasional (Jakarta: Rajawali Pers, 1996) at 19.

20 Fuady, M., Sosiologi Hukum Kontenporer (Interaksi Hukum, Kekuasaan, dan Masyarakat) (Jakarta: Kencana, 2011) at 61 .

21 Syahputra, E., \& Suteki., supra note 11 at 6.

22 Sunaryo, "Corporate Social Responsibility (CSR) Dalam Perspektif Pembangunan Berkelanjutan" Fiat Justitia Jurnal Ilmu Hukum, 7(1), 264-276 (2013) at 269. 
current neoliberalism. On the other hand, the community cannot arbitrarily make demands on corporations if their expectations are beyond applicable regulations' limits. The CSR liability arrangements are under current legal provisions in Indonesia, as follows: 23

\section{A.CSR in the Investment Act}

CSR obligations begin with the formation of Law no. 25 of 2007 concerning Capital Investment. This law was passed on April 26, 2007. CSR obligations are contained in Article 15 and Article 34 of the law. Article 15 letter b states that: "Every investor is obliged to: a. Apply the principles of good corporate governance; b. Carry out corporate social responsibility; c. Make a report on investment activities and submit them to; $d$. Capital Investment Coordinating Board; e. Respect the communities' cultural traditions around the location of investment business activities, and f. Comply with all statutory provisions".

According to Article 15 letter b of this law, the government requires investment for companies, both foreign investment corporations and domestic investment corporations, to carry out CSR. The definition of CSR referred to in this law is contained in the Elucidation of Article 15 letter b, states that "what is meant by corporate social responsibility is the responsibility inherent in every investment corporation to continue to create relationships that are harmonious, balanced, and by the environment, values, norms, and culture of the local community." Following this definition, CSR obligations are inherent in every investment corporation operating in the Republic of Indonesia's territory. The Investment Law does not state that corporations engaged in specific fields are required to carry out CSR.

\section{B. CSR in the Limited Liability Company Act}

Social and environmental responsibility or CSR is one of the things required by the Government through Law Number 40 of 2007 concerning Limited Liability Companies. This Law shall come into force on August 16, 2007. Article 74 states that: 1). The Company that carries on its business activities in the field and/or natural resources must carry out social and environmental responsibilities; 2). As referred to in paragraph (1), social and environmental responsibility is a corporate obligation that is budgeted and calculated as a company expense whose implementation is carried out with due regard to propriety and fairness; 3 ). Companies that do not carry out the obligations referred to in paragraph (1) are subject to sanctions by the legislation; and 4). Government regulations regulate further provisions regarding social and environmental responsibility;

Through Article 74 of Law Number 40 of 2007 concerning Limited Liability Companies, the government wants to strengthen the social dimension of the corporation. This is triggered by the many problems or conflicts between the

23 Ginting, J., "Tinjauan Yuridis Terhadap Corporate Social Responsibility (CSR) Dalam Good Corporate Governance (GCG)," Lex Jurnalica, 5(1), 17-34 (2007) at 20. 
corporation and the community around the corporation. In Chapter V, Article 74 of Law No. 40 of 2007 concerning Limited Liability Companies are stated, companies that carry out their business activities in the fields and/or related to natural resources must carry out social and environmental responsibilities. These social and environmental responsibilities are corporate obligations that are then budgeted and calculated as corporate costs whose implementation is carried out due to propriety and fairness. Corporations that do not carry out these obligations will be subject to sanctions under applicable laws and regulations. The elucidation of Article 74 paragraph (1) explains that this CSR obligation aims at creating a harmonious, balanced, and compatible corporate relationship with the environment, values, norms, and culture of the local community.

\section{CSR in the Environmental Management Act}

CSR that has been discussed in Indonesia is closely related to environmental conditions in our country. Poor handling of environmental conditions shows low responsibility not only from corporations but also from the community. ${ }^{24}$ This is proven by the fact that there are still many pollutions and environmental damage caused by the development process, which is a loss for the people, especially vulnerable people who sometimes do not understand that their right to a fair and healthy environment is protected by law. Thus, there have been violations of human rights in environmental cases that the public has not realized. ${ }^{25}$

Therefore, understanding CSR must not only be understood by corporations but must also be understood by the public. CSR requires corporations to increase the capacity and quality of life of surrounding communities and be more environmentally responsible. If we look at Law No. 23 of 1997 concerning Environmental Management (Environmental Management Law), emphasized that everyone has the right to play a role in environmental management and must preserve the environment. So that community participation in supporting CSR is essential for the realization of a good environment.

The Environmental Management Law also continues to emphasize the obligation for parties to make efforts to provide true and accurate information regarding environmental management. CSR's meaning also reflects through the provision listed in Article 6 paragraph (2) of the Law on Environmental Management.

Not only about the environment, but this law also reinforces CSR obligations regarding community empowerment. So the corporation is obliged to increase the capacity and quality of life of the surrounding community. This is stated in Article 7 paragraph (2) of the Law concerning Environmental Management. The following

24 Harahap, A.S., "Pengaturan Corporate Social Responsibility (CSR) Di Indonesia," Lex Jurnalica, 7(3), $182-190(2010)$ at 186.

25 Fahrial., Utama, A.S., \& Dewi S., "Pemanfaatan Corporate Social Responsibility (CSR) terhadap Pembangunan Perekonomian Desa" Jurnal Wawasan Yuridika, 3(2)251-264 (2019) at 259. 
articles in the Law on Environmental Management relating to CSR activities, namely: Article 5 paragraph (1), (2), and (3). Article 6 (1) and (2), and Article 7 (1) and (2).

In terms of regulation, the implementation of CSR has become the government's commitment. In the corporation of State-Owned Enterprises (BUMN) with the Community Development Partnership Program (PKBL), it is a manifestation of CSR, which is mandatory. Although many corporations in Indonesia have implemented CSR, it is still incidental and not integrated. There are three levels of orientation in implementing CSR: charity, partial, and oriented to increasing competitiveness.

Despite the growing pros and cons of debates in the business community, CSR regulations in Article 74 of the Law on Limited Liability Companies and Article 15 of the Investment Law are a form of progression in legal reform, especially in economic law development. CSR arrangements in the law form government interference that contains values to protect various aspects of human life. ${ }^{26}$ Economic actors, including a corporation, carry out social, economic, and environmental aspects of economic activities. It is crucial to the existing government intervention to maintain the balance of all parties' interests in practice. In this case, the interests of the corporation, society, and the environment. There is a mutual relationship between corporations as producers and communities as consumers.

Likewise, with nature and the environment and the communities around which the corporation operates. Replacing these two laws will not only replace, adjust to global trends but will be a fundamental overhaul of economic law that has paradigmatic qualities. In addition to aligning national interests with international rules, CSR regulation in legislation and its application will create economic justice for the community. ${ }^{27}$ The amendment to the Limited Liability Company Law and the Investment Law with the addition of CSR material is expected to be a foundation and guide economic actors in Indonesia in running business activities both on a national and global scale. Although Article 74 of the Law on Limited Liability Companies and Article 15 of the Investment Law only requires corporations and investments relating to natural resources and the environment to carry out CSR programs, in its implementation, it will be more progressive, not only focused on what is stated in the provisions of these laws and regulations. ${ }^{28}$

As in the progressive legal paradigm that "Law is for Humans" who refuse to maintain the status quo state in law, such as positivistic, normative, and legalistic ways, which must work with natural law formulations. ${ }^{29}$ Progressive law adheres to the paradigm of "Law is for Humans." Humans here are a symbol of the reality and dynamics of

26 Hartono, S.R., Hukum Ekonomi Indonesia (Malang: Bayu Media Publishing, 2007) at 13.

27 Harahap, A.S., supra note 17 at 189.

28 Ambarini, N.S.B., "Corporate Social Responsibility (CSR) Sebagai Instrumen Hukum Ekonomi di Era Globalisasi," Jurnal Dinamika Hukum, 10 (3), 308-318 (2010) at 317.

29 Rahardjo, S., Biarkan Hukum Mengalir (Jakarta: Penerbit Buku Kompas, 2007) at 138. 
life. The law guides and serves the community. Thus a balance is needed between "statics" and "dynamics" between rules and open roads. ${ }^{30}$

\section{SANCTIONS FOR CORPORATIONS'S AVOIDANCE TO CORPORATE SOCIAL RESPONSIBILITY}

The concept of CSR in Indonesia has been arranged in Law Number 25 of 2007 concerning Investment, Law Number 40 of 2007 concerning Limited Liability Companies, and Government Regulation Number 47 of 2012 concerning Social and Environmental Responsibility (Government Regulation of social and environmental responsibility).

Regulations related to CSR in Indonesia give different terms to CSR. Whereas in the Limited Liability Company Law and social and environmental responsibility Government Regulation, CSR is implemented as social and environmental responsibility. So when discussing CSR carried out by corporations, the term used is social and environmental responsibility. The reason for using the term social and environmental responsibility for a corporation is that the corporation is a legal entity that has been regulated explicitly in a Limited Liability Company Law.

When corporations engaged in natural resources do not conduct social and environmental responsibility by the provisions of the Limited Liability Company Law and social and environmental responsibility Government Regulations, it should be given sanctions. However, the provisions of the sanction of the Limited Liability Company Law and the social and environmental responsibility Government Regulations that refer to the relevant laws and regulations result in settlement of having to see the laws and regulations related to natural resources first. So the analysis related to the regulation of social and environmental responsibility sanctions in the Limited Liability Company Law, social and environmental responsibility Government Regulations, Investment Law, and legislation relating to natural resources needs to be done to obtain legal certainty in law enforcement and can prevent damage to the environment and surrounding communities.

\section{A..Sanction According to the Limited Liability Companies Act and Government Regulation} on Social and Environmental Responsibility

Sanctions for not implementing social and environmental responsibility are regulated in Article 74 paragraph (3) of the Limited Liability Companies Law and Article 7 of Social and Environmental Responsibility Government Regulation. The provisions in Article 74 paragraph (3) of the Limited Liability Companies Law and Article 7 of the Social and Environmental Responsibility Government Regulation, which states "Subject to sanctions by statutory provisions," are uncertain or general formulations and do not

30 Rahardjo, S., Penafsiran Hukum yang Progresif (Prawacana) dalam Buku Semiotika Hukum dari Dekonstruksi Teks Menuju Progresivitas Makna (Bandung: Refika Aditama, 2005) at 14. 
explicitly refer to the designated legislation. Imposing sanctions like this can be carried out arbitrarily by law enforcement.

Sanction arrangements given to related laws and regulations must have similarities in the subject of norms, the same behavior, and the same legal sanctions. If these three factors have in common between the Limited Liability Company Law and the social and environmental responsibility Government Regulation with related regulations, sanctions can be implemented based on the relevant laws and regulations. ${ }^{31}$

\section{B. Sanction According to the Investment Act}

The term social and environmental responsibility is unknown in investment law. The implementation of CSR in investment law uses the term CSR. The provisions of CSR in the Investment Law explain that CSR is an obligation that must be carried out by investors. When investors do not carry out obligations, investors will get sanctions that are regulated in Article 34 paragraph (1) of the Investment Law, namely administrative sanctions consisting of written warnings, restrictions on business activities, freezing, or revocation of business activities or investment facilities.

\section{Sanction According to the Natural Resources Act}

The regulation of social and environmental responsibility in legislation relating to natural resources is still a weakness. When the Limited Liability Company Law and social and environmental responsibility are to Government Regulation in delegating sanctions to the laws and regulations, it is expected that regulations related to natural resources have governed social and environmental responsibility sanctions. However, this delegation has not provided legal certainty because there are still regulations in natural resources that have not provided social and environmental responsibility sanctions.

Regulations that have not yet been regulated concerning social and environmental responsibility sanctions are Law Number 41 of 1999 concerning Forestry, Law Number 22 of 2001 concerning Oil and Gas, and Law Number 7 of 2004 concerning Water Resources. In comparison, the regulations that have provided provisions related to sanctions against social and environmental responsibility are Law Number 5 of 1960 Concerning Basic Agrarian Regulations, Law Number 5 of 1984 concerning Industry, Law Number 27 of 2003 concerning Geothermal Energy, Law Number 4 of 2009 concerning Mineral and Coal Mining, Law Number 30 of 2009 concerning Electricity, and Law Number 45 of 2009 concerning Fisheries.

When the regulations governing natural resources and the ethics of running a corporation have set sanctions related to social and environmental responsibility, corporations that do not implement social and environmental responsibility in natural resources can be directly sanctioned by the laws that govern them. However, when the

31 Marthin., Salinding, M.B., \&\&Akim, I., "Implementasi Prinsip Corporate Social Responsibility (CSR) Berdasarkan Undang-Undang Nomor 40 Tahun 2007 Tentang Perseroan Terbatas”, J. Priv. \&e Com. L, l(1), 111-132 (2017) at 121. 
Limited Liability Company Law and the social and environmental responsibility Government Regulation mandate related regulations to regulate sanctions and it turns out that the regulations have not yet regulated them, then the form of social and environmental responsibility sanctions against corporations results in a legal vacuum. Provisions for using sanctions regulated in related legislation are mandates from the Limited Liability Company Law and social and environmental responsibility Government Regulations. However, the two rules also do not explicitly regulate, so they must look at more general laws, such as the Investment Law.

Corporations that also include investors are subject to the Investment Act. The Investment Law has set sanctions for investors who do not implement social and environmental responsibility; in this case, the corporation. However, the return of regulations to the Investment Law provides ambiguity and is ambiguous for those involved in implementing social and environmental responsibility in Indonesia. ${ }^{32}$ When there should be a more specific regulation that regulates, then the rule has been explicitly set.

\section{Sanctions of Social and Environmental Responsibility in Several Countries}

Although there are different concepts in social and environmental responsibility or CSR, both use the same principle, the Triple P principle (Profit, People, and Planet), which was popularized by John Elkington. Then, the Indonesian government can make CSR arrangements found abroad as a consideration in providing sanctions for not implementing social and environmental responsibility in Indonesia. CSR is a concept that has been applied abroad, especially in industrialized countries. Developed countries consider that CSR is a concept based on ethical and moral values so that it is done voluntarily. Developed countries are divided into two legal systems, namely civil law systems and standard law systems. ${ }^{33}$

France and the United Kingdom are two countries with different legal systems. Although both have different legal systems, both countries implement CSR voluntarily. However, the United Kingdom and France have regulated CSR in their regulations. Both have different orientations in implementing CSR. ${ }^{34}$ The United Kingdom is more oriented towards shareholders, while the French state is more oriented towards stakeholders, namely the community. France is a civil law country. The French state has implemented CSR in its country by issuing amended regulations, the Nouvelles Regulations Economiques (NRE). There are still weaknesses in the NRE, namely the absence of sanctions against corporations that do not comply with regulations.

\footnotetext{
Marthin., Salinding, M.B., \&Akim, I., supra note 24 at 129.

Ayu, I.K., "Analisis Yuridis Pemberian Sanksi dalam Pelaksanaan Tanggung Jawab Sosial dan Lingkungan Oleh Perseroan Terbatas Yang Bergerak di Bidang Sumber Daya Alam," Kumpulan Jurnal Mahasiswa Fakultas Hukum, 1(5), 1-20 (2013) at 13.

34 Chauvey, J.N, et al. "The Normativity And Legitimacy Of CSR Disclosure: Evidence From France," Journal of Business Ethics, 130(4), 789-803 (2015) at 790.
} 
Nevertheless, when corporations in France do not carry out CSR by stakeholder expectations, sanctions are obtained. ${ }^{35}$

Theoretically, the government should create adequate pre-conditions so that corporations can operate with high legal certainty. ${ }^{36}$ In this case, various existing regulations not only serve to provide a minimum performance limit for corporations but also protect corporations that have implemented CSR. Also, when regulations made by the government protect the interests of the corporation, the government gives obligations to the corporation to pay attention to the social and environmental conditions around the corporation. So that corporations engaged in natural resources do not carry out their obligations, then sanctions should be given. ${ }^{37}$

The regulation on sanctions for not implementing CSR by corporations engaged in natural resources in Indonesia has not been regulated. The Limited Liability Company Law and the social and environmental responsibility Government Regulation governing CSR implementation in Indonesia still delegate sanction provisions based on relevant laws and regulations. Related laws and regulations are legislation relating to natural resources and the ethics of conducting business activities. It turns out that several regulations are governing natural resources that do not regulate the sanctions for not implementing CSR. So it is needed a form of sanctions that is not implemented the right CSR to provide a deterrent effect to corporations engaged in natural resources.

The definition of sanctions is dependents (actions, penalties) to force people to keep agreements or comply with the law (articles of association, associations). ${ }^{38}$ The Big Indonesian Dictionary distinguishes sanctions into two, namely negative rewards and positive rewards. Sanctions in positive rewards can be given to corporations engaged in the field of natural resources implementing CSR. Negative rewards in the form of burdens or sufferings are determined in the law, while positive rewards in gifts or gifts are specified in law. ${ }^{39}$

Positive rewards in the form of awards are realized by the provision of facilities or tax incentives. Tax incentives for corporations that have carried out CSR can motivate corporations to continue to be consistent in carrying out CSR activities because they can reduce the amount of tax imposed on corporations. ${ }^{40}$ Conceptually, CSR is an approach where corporations integrate social care in their business operations and their interactions with stakeholders based on the principle of volunteerism and

35 Avetisyan, E., \& Ferrary, M., "Dynamics of Stakeholders' Implications in the Institutionalization of the CSR Field in France and the United States," Journal of Business Ethics, 115(1), 115-133 (2013) at 121.

36 Asy'ari, H., Implementasi Corporate Responsibility (CSR) Sebagai Modal Sosial pada PT Newmont (Tesis: Fakultas Hukum Universitas Brawijaya, 2009) at 78.

37 Utama, A.S. "Problems in the Implementation of Corporate Social Responsibility of Forestry and Plantation Companies in Pelalawan District," KnE Social Sciences, 325-331 (2019) at 329.

38 Departemen Pendidikan Nasional, Kamus Besar Bahasa Indonesia (Jakarta: Gramedia, 2004) at 1224.

39 Departemen Pendidikan Nasional, supra note 19 at 1224.

40 Buhmann, K., "The Danish CSR Reporting Requirement as Reflexive Law: Employing CSR as a Modality to Promote Public Policy Objectives through Law," European Business Law Review, 24(2), 187-216 (2013) at 192. 
partnership. ${ }^{41}$ So that when corporations do not implement CSR, there will be no legal sanctions imposed on them but only limited to moral sanctions. Corporation, namely moral sanctions that come from the community. Such sanctions can be in the form of a boycott of purchases and negative campaigns. ${ }^{42}$

The UK is included in the common law system, which makes jurisprudence a significant law source that has provided regulations related to corporations in implementing CSR. The UK has a regulation related to CSR, the Corporate Responsibility Bill. Under Article 11 of the Corporate Responsibility Bill, corporations that do not implement CSR have committed violations and may be subject to sanctions: a). Prison or fines or both; b). People who are prohibited from becoming corporate directors for a specified period or year; c). People who are required to provide compensation to everyone who has suffered due to any violation; d). the company is suspended from trading or exchanging shares; and e). In case of continuous violation of the law, the company is intended to cease certain operations or activities. ${ }^{43}$

The application of CSR in several developed countries, such as the United Kingdom and France, has become a legal assessment by the capital market authority. It is outlined in the form of a public report and the assessment of the public itself. It turns out that corporations that carry out CSR in their business activities get rewards in the form of competitive advantages so that the stock price strengthens in the stock market compared to corporations that have ethical behavior.

The concept of CSR that has been applied by some business actors engaged in natural resources in Indonesia becomes a problem when the Government implements CSR into social and environmental responsibility following regulations in Indonesia. The legislators involved in making regulations related to social and environmental responsibility in the Limited Liability Company Law and Government Regulations social and environmental responsibility no longer use CSR but social and environmental responsibility that is adjusted to Indonesia's business culture. This has resulted in debates between business actors and the government because by changing terms and concepts to social and environmental responsibility, business actors can no longer voluntarily implement CSR.

The application of social and environmental responsibility in Indonesia is a responsibility in the sense of liability. The primary responsibility of social and environmental responsibility has been stated in the Limited Liability Company Law, which is clarified in Government Regulation's social and environmental responsibility. Thus, the application of social and environmental responsibility as a liability is a legal policy forming a law to regulate and implement social and environmental responsibility accompanied by sanctions. The regulation of social and environmental responsibility becomes a legal obligation in Indonesia, which has more legal certainty than CSR, which is only voluntary.

41 Suharto, E., Pekerjaan Sosial di Dunia Industri Memperkuat CSR (Corporate Social Responsibility), (Bandung: Alfabeta, 2009), at 103.

42 Ayu, I.K., supra note 26, at 18.

43 Utama, A.S., \& Rizana. supra note 26, at 180. 


\section{THE IMPORTANCE OF REGULATING CORPORATE CRIMINAL LIABILITY IN RESPONSE TO THE CSR AVOIDANCE}

The implementation of CSR so far has only been based on corporate awareness and commitment. At the same time, each corporation's commitment and awareness are not the same and very much depend on their respective corporate policies. Dependent on the implementation of CSR on corporate awareness and commitment has several weaknesses. The most fundamental weakness is the absence of strict sanctions for corporations that do not implement CSR. This condition will not encourage the implementation of CSR in Indonesia. So far, corporations that carry out CSR do not have a clear direction even though there are so many benefits to be gained if CSR is implemented with clear rules and directives. ${ }^{44}$

For example, if CSR is directed at specific sectors such as education, how many benefits are obtained, poor people will be helped by this CSR to improve the quality of their education. The government will also be significantly helped in carrying out its responsibilities in the intelligence of the nation's life. Of course, that can all be done if there are clear regulations on CSR. The disadvantage of the absence of clear CSR regulations is that people and the state are increasingly disadvantaged. Various events in Indonesia, such as mud floods, floods due to forest logging, and environmental pollution in various places, show that CSR's implementation is absolute. If current conditions continue, the people and the state will bear the most significant losses.

CSR regulation is not new in the corporate world. In various developed countries, every corporation has been required to implement CSR and report it periodically. ${ }^{45}$ This is done to monitor and control the CSR implementation of each corporation. Existing regulations also provide strict sanctions for violations of the implementation of CSR. Sanctions are given starting from the mild ones such as written warnings to issue from the trading floor for corporations to go public. ${ }^{46}$ Of course, the Act to be made must be adjusted to the conditions in Indonesia. Existing laws must be able to bridge the interests of all parties. Business actors with profit motives certainly will not agree if the existing regulations interfere with their interests. As the corporation's presence impacts the party, the community demands a real contribution to their lives. Therefore the law must be able to accommodate all stakeholders. ${ }^{47}$

If a corporation not implementing CSR can be prosecuted or negligent, then the question arises; what and how can a corporation, even if it does not have a human spirit, fulfill the element of intent and neglect? To answer that question, an opinion expressed by Muladi will be made, which confirms that the problem that arises may be

44 Tanudjaja, B.B., "Perkembangan Corporate Social Responsibility di Indonesia." Nirmana, 8(2), 92-98, (2006) at 94.

45 Siregar, B.G., "Penerapan Corporate Social Responsibility (CSR) Dalam Pandangan Islam," Juris, 14(2), $135-150,(2015)$ at 140.

46 Tanudjaja, B.B., supra note 32 at 95.

47 Yusuf, M.Y., Islamic Corporate Social Responsibility (I-CSR) Pada Lembaga Keuangan Syariah (LKS), (Depok: Kencana, 2017), at 79. 
about what measures can be used as a guideline for corporate responsibility. Another problem is how to determine corporate intentions and omissions. In his writing "Accountability of Legal Entities in Criminal Law," Muladi stated two guidelines for determining the intentions and omissions of corporations, namely: ${ }^{48}$ a). To be accountable for the corporation can be solved by looking at whether the actions of the corporation's management within the framework of the corporate statutory goals and or by corporate policy. It is sufficient to see whether corporate actions are by the corporation's scope of work (feitelijke werkzaamheiden). Corporate behavior is not readily accepted if corporate actions in society are not considered corporate behavior; and b). To determine the intentional and negligence of a corporation, it can be done by looking at Whether the intentional act of managing a corporation is included in corporate politics or is in the actual activities. So it must be detected through the psychiatric atmosphere (psychish klimaat) that applies to the corporation. With the construction of responsibility (tearekenings-constructie), individual intentions (naturlijk persoon) acting on behalf of the corporation can become corporate intentions. ${ }^{49}$

This corporate criminal liability can also refer to Article 49 of the 2015 Criminal Code Bill. It states, "Corporations commit criminal acts if they are carried out by people who have functional positions in the corporate organizational structure acting for and on behalf of the corporation or in the interests of the corporation, based on employment relationships or based on other relationships, within the scope of the corporation's business, either individually or together." Furthermore, Article 50 of the Criminal Code Bill states that "If a corporation commits a criminal act, criminal liability is imposed on the corporation and/or its management or corporate controlling personnel." Furthermore, Article 51 of the Penal Code Draft states that "Corporations can be criminally liable for an act committed for and/or on behalf of a corporation if the act is included in the scope of their business as specified in the articles of association or other provisions applicable to the corporation concerned." While the restriction is regulated in Article 52 of the Criminal Code Bill, "The criminal liability of the corporate management is limited as long as the management has a functional position in the corporation's organizational structure." 50

The use of the term sanctions (not criminal) is based on why the definition of sanctions is broader compared to criminals. In criminal law (KUHP or other laws and regulations), unlawful use is only limited to forms of sanctions or penalties according to ius constitumum contained in Article 10 of the Criminal Code and according to ius constituendum Article 66 through Article 68 of the 2015 Criminal Code Bill for criminal types and Article 103 of the 2015 Criminal Code Bill for types of sanctions. In contrast, sanctions are not only limited to Article 10 of the Criminal Code because many of the

48 Hatrik, H., supra note 8 at 93.

49 Utama, A.S., Rizana., \& Putra, T.A., "Tanggung Jawab Sosial Perusahaan PT Asia Forestama Raya di Kota Pekanbaru dan Penegakan Hukumnya," Pagaruyuang Law Journal, 2(2), 148-162 (2019) at 150.

50 Ratomi, A. "Korporasi Sebagai Pelaku Tindak Pidana (Suatu Pembaharuan Hukum Pidana Dalam Menghadapi Arus Globalisasi Dan Industri)," Al Adl: Jurnal Hukum, 10(1), 1-22 (2018) at 5. 
laws outside the Criminal Code that adhere to sanctions (in the form of disciplinary action) are threatened by perpetrators of criminal acts, especially corporations.

Penalties (imposing sanctions) on corporations, often associated with financial problems, actually contain further goals. This can be seen from the view of Wolfgang Friedmann in his book entitled Law in Changing Society as quoted by Muladi, which states "the main effect and usefulness of a criminal conviction imposed upon a corporation can be seen either in any personal injury or, in most cases, in the financial detriment, but in the public opprobrium and stigma that attaches to a criminal conviction $^{51}$

Likewise, what was stated by Yoshio Suzuki in his book The Role of Criminal Law in the Control of Social and Economic Offenses, as also quoted by Muladi, stated that in imposing penalties on corporations carried out carefully, especially about closing all or part of the corporation? Because this will have a far-reaching impact. Not only will those who suffer wrong, but also society, especially workers who will be threatened with employment termination. ${ }^{52}$

CSR that can be given by corporations is already regulated in many laws and regulations, such as Law No. 19 of 2003 concerning State-Owned Enterprises (BUMN Law), Law on Investment, and Limited Liability Companies Law. The law explains corporate obligations to carry out social responsibility. The law regulates sanctions, but sanctions in the SOE Law, the Limited Liability Company Law is unclear about the sanctions imposed on corporations that do not implement CSR. Whereas the Investment Law is subject to administrative sanctions for corporations that do not implement CSR, but the administrative sanctions applied are considered to be less effective in making corporations aware of the importance of implementing CSR in order to balance or harmony between corporations and the community so that criminal sanctions as ultimum remidium need to create legal certainty.

Munir Fuady revealed that currently developing models of non-conventional criminal penalties are considered suitable and can be applied to corporations that do not implement CSR. The models are: ${ }^{53}$ a. Probation, in this sentence, the corporation is sentenced within a certain period and monitored; b. Equity Fine, corporations subject to criminal liability in the form of fines are fines paid to the government, which constitute the corporation's shares granted to the government; c. Diversion Becomes Individual Punishment; d. Additional Penalties, Such as revocation of permits and prohibitions on certain activities or activities in other fields; e. Community Service Penalty, this punishment is effective for a corporate crime that has harmed society so that the community gets some sort of compensation from the results of the execution of the sentence; f. Juridical Authority of Outside Parties of the Company, an outsider authorized to a corporation that is liable for criminal liability in the context of this sentence, may take

51." Muladi, Pelaksanaan Pemidanaan di Bidang Hukum Ekonomi (Jakarta: FH-UNKRI, 1989) at 8.

52 Muladi, supra note 25 at 9.

53 Fuady, M., Doktrin-Doktrin Modern Dalam Corporate Law dan Eksistensinya Dalam Hukum Indonesia (Bandung: Citra Aditya Bakti, 2002) at 29. 
the authority to enter and regulate the company subject to the sanction. For example, the Investment and Financial Institution Supervisory Agency (BAPEPAM) for publicly listed companies or financial authorities for banking companies; and g. Obligation to buy shares, this penalty is the obligation to buy shares by taking funds from victim compensation funds taken to buy shares of the shareholders at market prices so that the company's actions do not harm him.

Indeed, today the provisions of criminal law do not differentiate their arrangements. That is, the form of criminal sanctions aimed at people and corporations is united in a single package of criminal types. This model has been adopted in most countries, which codifies the provisions of criminal law. Meanwhile, if using a model that distinguishes forms of criminal sanctions for people and corporations, it is necessary to look for criteria about the basis or reasons for the distinction, especially in the context of determining the criteria or categories of principal and additional penalties. ${ }^{54}$ These criteria can be seen from the corporation's definition, the benefits of corporate punishment when criminal sanctions should be given to the corporation.

Criminal liability is intended to determine whether a defendant is responsible for a crime that occurred or not. ${ }^{55}$ If linking criminal liability with CSR, CSR is not carried out by the corporation must meet criminal acts' elements. Corporations that currently have great strength in production can produce maximum profits. However, the desire to obtain maximum profits can harm society, which can be in the form of damage to natural resources and human resources. ${ }^{56}$ Natural resources and human resources are the scopes of the implementation of CSR. However, CSR, which is not carried out by corporations engaged in natural resources, does not meet criminal acts' elements. Thus, corporations engaged in natural resources cannot be subject to criminal sanctions when not implementing CSR. ${ }^{57}$

Criminal sanctions are needed for corporations that do not implement CSR because they are seen as a function or strategic role for corporations owned by CSR; that is, corporations can build and enhance a good image for the corporation itself and improve the corporation's business sector. Through CSR, corporations can also improve the welfare and socio-economic life of local communities and the wider community. This condition will guarantee the smooth running of corporate production activities or activities and the marketing of corporate production. Whereas corporations protecting the environment and nature can support the sustainability of corporate activities. ${ }^{58}$

54 Bawono, B. T., \& Mashdurohatun, A., "Penegakan Hukum Pidana Di Bidang Illegal Logging Bagi Kelestarian Lingkungan Hidup Dan Upaya Penanggulangannya," Jurnal Hukum, 26(2), 590-61l (2011) at 599.

55 Krismen, Y., "Pertanggungjawaban Pidana Korporasi Dalam Kejahatan Ekonomi”, Jurnal Ilmu Hukum, 5(1), 61-70 (2014) at 63.

56 Widjaya, G., \& Pratama, Y.A., Risiko Hukum \& Bisnis Perusahaan Tanpa CSR (Jakarta: Forum Sahabat, 2008) at 65.

57 Utama, A.S., Rizana., \& Putra, T.A., supra note 44 at 159.

58 Satria, H., "Penerapan Pidana Tambahan dalam Pertanggungjawaban Pidana Korporasi Pada Tindak Pidana Lingkungan Hidup," Jurnal Yudisial, 10(2), 155-171 (2017) at 162. 


\section{CONCLUSION}

CSR in Indonesia has become an obligation that must be undertaken by the corporation. Implementation of CSR in Indonesia is not a voluntary trait but is an obligation. There are obligations set in the legislation, in this case, there are in the Law on Limited Liability Companies, Law on State-Owned Enterprises, Law on Investment, Law on Environmental Management, Regulations Government on Social and Environmental Responsibility. However, there is no mention of criminal sanctions that are applied if a corporation does not implement CSR from several laws. Sanctions that are also applied in some of these laws are a delegation of rules regarding sanctions in the relevant laws and regulations, so it must first see the relevant laws and regulations. Only one law that applies clear sanctions is regulated in the Investment Law, which states administrative sanctions. Administrative sanctions that are applied when violations occur are less than optimal compared to the community's losses.

Criminal sanctions serve to provide a deterrent effect to the perpetrators, besides criminal sanctions also function as a tool to prevent violations in the future. This method is effectively used as a sanction if the corporation does not implement CSR. The need for corporate punishment is due to several important things. For example, the corporation in public life has an important role, CSR has a significant impact on society, administrative sanctions lack the force to force this because sanctions are applied lightly, and there are still violations of CSR not being implemented by the corporation, then also criminal sanctions have coercive power. Criminal sanctions are a form of ultimum remidium sanctions as a last resort if the other sanctions can not overcome criminal acts.

Arrangements regarding CSR should be clarified again regarding the corporation's minimum standards, so there is harmony about the regulation, both concerning sanctions and the implementation of CSR. It is time for corporations to care about the implementation of CSR because implementing CSR in corporate activity has positive benefits, not only the economic benefits that will be obtained by the corporation but also CSR can avoid conflicts between the corporation and the community and also carry out CSR for the sustainability of corporate business activities. Criminal sanctions are needed for corporations that do not implement CSR because seen from the aim of CSR is to improve people's lives and improve people's welfare, and also CSR can improve a country's economic growth.

\section{ACKNOWLEDGMENTS}

None.

\section{COMPETING INTERESTS}

The authors declare that they have no competing interests. 


\section{REFERENCES}

Ambarini, N.S.B., "Corporate Social Responsibility (CSR) Sebagai Instrumen Hukum Ekonomi Di Era Globalisasi”, (2010) Jurnal Dinamika Hukum, 10(3), 308-318.

Asy'ari, H., Implementasi Corporate Responsibility (CSR) Sebagai Modal Sosial pada PT Newmont, (Tesis: Fakultas Hukum Universitas Brawijaya, 2009).

Avetisyan, E., \& Ferrary, M., "Dynamics of Stakeholders' Implications in the Institutionalization of the CSR Field in France and the United States," (2013) Journal of Business Ethics, 115(1), 115-133.

Ayu, I.K., "Analisis Yuridis Pemberian Sanksi dalam Pelaksanaan Tanggung Jawab Sosial dan Lingkungan Oleh Perseroan Terbatas Yang Bergerak di Bidang Sumber Daya Alam", (2013) Kumpulan Jurnal Mahasiswa Fakultas Hukum, 1(5), 1-20.

Bawono, B. T., \& Mashdurohatun, A., "Penegakan Hukum Pidana Di Bidang Illegal Logging Bagi Kelestarian Lingkungan Hidup Dan Upaya Penanggulangannya”, (2011) Jurnal Hukum, 26(2), 590-611.

Buhmann, K., "The Danish CSR Reporting Requirement as Reflexive Law: Employing CSR as a Modality to Promote Public Policy Objectives through Law," (2013) European Business Law Review, 24(2), 187-216.

Carroll, A.B., "Corporate Social Responsibility: Evolution of a Definitional Construct," (1999) Business \& Society, 38(3), 268-295.

Chauvey, J.N, et al. "The Normativity and Legitimacy of CSR Disclosure: Evidence from France," (2015) Journal of Business Ethics, 130(4), 789-803.

Departemen Pendidikan Nasional, Kamus Besar Bahasa Indonesia, (Jakarta: Gramedia, 2004).

Disemadi, H.S., \& Jaya, N.S.P., "Perkembangan Pengaturan Korporasi Sebagai Subjek Hukum Pidana Di Indonesia”, (2019) Jurnal Hukum Media Bhakti, 3(2), 118127.

Disemadi, H. S., \& Prananingtyas, P. "Kebijakan Corporate Social Responsibility (CSR) sebagai Strategi Hukum dalam Pemberdayaan Masyarakat di Indonesia", (2020) Jurnal Wawasan Yuridika, 4(1), 1-16.

Disemadi, H. S. "Consumer Protection of Flight Services through Corporate Social Responsibility Implementation in Indonesia" (2020) Journal of Private and Commercial Law 4 (1), 14-21.

Djakfar, M., "Corporate Social Responsibility: Aktualisasi Ajaran Ihsan Dalam Bisnis", (2013) Ulul Albab Jurnal Studi Islam, 11(1), 111-130.

Fahrial., Utama, A.S., \& Dewi S., "Pemanfaatan Corporate Social Responsibility (CSR) terhadap Pembangunan Perekonomian Desa" (2019) Jurnal Wawasan Yuridika, 3(2)251-264.

Fuady, M., Doktrin-Doktrin Modern Dalam Corporate Law dan Eksistensinya Dalam Hukum Indonesia, (Bandung: Citra Aditya Bakti, 2002).

Fuady, M., Sosiologi Hukum Kontenporer (Interaksi Hukum, Kekuasaan, dan Masyaraka), (Jakarta: Kencana, 2011).

Ginting, J., "Tinjauan Yuridis Terhadap Corporate Social Responsibility (CSR) Dalam Good Corporate Governance (GCG)", (2007) Lex Jurnalica, 5(1), 17-34.

Harahap, A.S., "Pengaturan Corporate Social Responsibility (CSR) Di Indonesia", (2010) Lex Jurnalica, 7(3), 182-190. 
Hakim, D. A., \& Ispriyarso, B. "Pemenuhan Hak-Hak Tenaga Kerja Melalui Penerapan Corporate Social Responsibility Pada Suatu Perusahaan (Studi Penerapan CSR Di PT. Great Giant Pineapple, Provinsi Lampung)", (2020) Law Reform, 12(2), 197-208.

Hartono, S.R., Hukum Ekonomi Indonesia, (Malang: Bayu Media Publishing, 2007).

Hasnati., Dewi, S., \& Utama, A.S., "Perbandingan Prinsip Good Corporate Governance Pada Bank Konvensional dan Bank Syariah dalam Sistem Hukum di Indonesia", (2019) Mizan: Journal of Islamic Law, 3(2), 197-208.

Hatrik, H., Asas Pertanggungjawaban Pidana Korporasi Dalam Hukum Pidana Indonesia, (Bandung: Alumni, 1996).

Iqbal, M., \& Sudaryanto, T., "Tanggungjawab Sosial Perusahaan (Corporate Social Responsibility) dalam Perspektif Kebijakan Pembangunan Pertanian”, (2016) Analisis Kebijakan Pertanian, 6(2)155-173.

Kashyap, R., Mir, R., \& Mir, A., "Corporate Social Responsibility: A Call For Multidisciplinary Inquiry," (2004) Journal of Business \& Economics Research, 2(7), 51-58.

Krismen, Y., "Pertanggungjawaban Pidana Korporasi Dalam Kejahatan Ekonomi", (2014) Jurnal Ilmu Hukum, 5(1), 61-70.

Marthin., Salinding, M.B., \&\&Akim, I., "Implementasi Prinsip Corporate Social Responsibility (CSR) Berdasarkan Undang-Undang Nomor 40 Tahun 2007 Tentang Perseroan Terbatas", (2017) J. Priv. \& Com. L, 1(1), 111-132.

Muladi, \& Priyatno, D., Pertanggungjawaban Pidana Korporasi, (Jakarta: Kencana, 2009).

Muladi, Pelaksanaan Pemidanaan di Bidang Hukum Ekonomi, (Jakarta: FH-UNKRI, 1989).

Rahardjo, S., Biarkan Hukum Mengalir, (Jakarta: Penerbit Buku Kompas, 2007).

Rahardjo, S., Hukum Dalam Perspektif Sejarah Sosial Dalam Pembangunan Hukum Dalam Perspektif Politik Hukum Nasional, (Jakarta: Rajawali Pers, 1996).

Rahardjo, S., Penafsiran Hukum yang Progresif (Prawacana) dalam Buku Semiotika Hukum dari Dekonstruksi Teks menuju Progresivitas Makna, (Bandung: Refika Aditama, 2005).

Ratomi, A. "Korporasi Sebagai Pelaku Tindak Pidana (Suatu Pembaharuan Hukum Pidana Dalam Menghadapi Arus Globalisasi Dan Industri)", (2018) Al Adl: Jurnal Hukum, 10(1), 1-22.

Satria, H., "Penerapan Pidana Tambahan dalam Pertanggungjawaban Pidana Korporasi Pada Tindak Pidana Lingkungan Hidup”, (2017) Jurnal Yudisial, 10(2), 155-171.

Setiyono, Kejahatan Korporasi, (Malang: Banyumedia Publishing, 2009).

Siregar, B.G., "Penerapan Corporate Social Responsibility (CSR) Dalam Pandangan Islam", (2015) Juris, 14(2), 135-150.

Suharto, E., Pekerjaan Sosial di Dunia Industri Memperkuat CSR (Corporate Social Responsibility), (Bandung: Alfabeta, 2009).

Sunaryo, "Corporate Social Responsibility (CSR) Dalam Perspektif Pembangunan Berkelanjutan”, (2013) Fiat Justitia Jurnal Ilmu Hukum, 7(1), 264-276.

Syahputra, E., \& Suteki, "Strategi Baru Pengentasan Kemiskinan Melalui Hukum Sebagai Sarana Pemberdayaan Corporate Social Responsibility", (2017), MasalahMasalah Hukum, 46(1), 1-8.

Tanudjaja, B.B., "Perkembangan Corporate Social Responsibility di Indonesia". (2006) Nirmana, 8(2), 92-98. 
Utama, A.S. "Problems in the Implementation of Corporate Social Responsibility of Forestry and Plantation Companies in Pelalawan District," (2019) KnE Social Sciences, 325-331.

Utama, A.S., \& Rizana, "Implementasi Corporate Social Responsibility PT Riau Crumb Rubber Factory Terhadap Masayarakat Kelurahan Sri Meranti Kota Pekanbaru", (2017) Jurnal Hukum Novelty, 8,(2).

Utama, A.S., \& Rizana., "Pelaksanaan Corporate Social Responsibility Dalam Rangka Optimalisasi Pelestarian Lingkungan", (2020) Litigasi, 19(2), 127-147.

Utama, A.S., Rizana., \& Putra, T.A., "Tanggung Jawab Sosial Perusahaan PT Asia Forestama Raya di Kota Pekanbaru dan Penegakan Hukumnya", (2019) Pagaruyuang Law Journal, 2(2), 148-162.

Widjaya, G., \& Pratama, Y.A., Risiko Hukum \& Bisnis Perusahaan Tanpa CSR, (Jakarta: Forum Sahabat, 2008), at 65.

Yusuf, M.Y., Islamic Corporate Social Responsibility (I-CSR) Pada Lembaga Keuangan Syariah (LKS), (Depok: Kencana, 2017). 
230 | Corporation's Criminal Liability in Indonesia: A Response to the Weak Enforcement of Corporate Social Responsibility

This page is intentionally left blank 